\title{
Izabella Bukraba-Rylska
}

\section{O potrzebie i korzyściach z badania wsi i rolnictwa w Polsce}

Streszczenie: Artykuł prezentuje argumenty przemawiające za poznawczymi, teoretycznymi i metodologicznymi korzyściami płynącymi z badania wsi i rolnictwa. Wbrew często powtarzanym opiniom zawdzięczającym swoje istnienie antyruralistycznej orientacji nauk społecznych, procedurom orientalizowania czy miejskiemu szowinizmowi nie są to zjawiska mało ważne we współczesnym świecie: wciąż stanowią znaczną część aktualnej rzeczywistości społeczno-ekonomicznej, od ich istnienia zależy kształt wielu innych istotnych procesów i wydarzeń, a ich badanie pozwala weryfikować i falsyfikować utarte sądy, w tym wiele uznanych koncepcji naukowych. Także dorobek polskiej socjologii wsi, ekonomiki rolnictwa czy historii gospodarczej - w większości przypadków mający charakter interdyscyplinarny - okazuje się w świetle późniejszych osiągnięć nauki światowej prekursorski i doniosły, co wskazuje, że problemy wsi i rolnictwa stanowią wciąż obiecujący obszar badawczy.

Słowa kluczowe: wiejskość jako paradygmat, podejście interdyscyplinarne, odkrywcza mikrodeskrypcja, szansa dla nauki polskiej.

Problematyka wsi i rolnictwa tylko pozornie wydaje się takim samym tematem badań naukowych jak każdy inny. W istocie stanowi temat szczególny i pod wieloma względami wyjątkowy. Po pierwsze nie chodzi tu o badanie jakiegoś określonego zjawiska (kulturowego, społecznego czy ekonomicznego) zachodzącego na danym obszarze, ale - pośrednio bądź bezpośrednio - także o badanie określonego obszaru (miejsca, przestrzeni, środowiska), gdzie te różne zjawiska zachodzą. Po drugie, zajmowanie się wsią i rolnictwem oznacza w wielu przypadkach konieczność zastosowania interdyscyplinarnego podejścia, tak aby analizowane problemy zostały naświetlone nie jednostronnie, ale możliwie w pełny, kompleksowy sposób, a więc

Prof. dr hab. Izabella Bukraba-Rylska, Instytut Rozwoju Wsi i Rolnictwa PAN, ul. Nowy Świat 72, 00-330 Warszawa, bukryl@gmail.com. 
właściwie rozpoznane. I po trzecie wreszcie, sam przedmiot takich wszechstronnych analiz obciążony jest niejednokrotnie tyloma uprzedzeniami i fałszywymi sądami (które nie dość, że zdominowały myślenie potoczne, to jeszcze przeniknęły do aparatury pojęciowej i teoretycznej wielu dyscyplin), że rodzi to potrzebę wyjątkowo uważnego i refleksyjnego traktowania zarówno każdorazowo wybranego zagadnienia, jak i stosowanych wobec niego założeń, metod i narzędzi badawczych. Tematem poniższych rozważań będą zatem te trzy istotne uwarunkowania analiz wsi i rolnictwa, a celem prowadzonych rozważań - wyjaśnienie złożoności sytuacji, zakwestionowanie najczęściej formułowanych stereotypowych opinii oraz podkreślenie faktycznej roli traktowanego całościowo segmentu agrarnego. Wszystko to, jak się okaże, może mieć swoje znaczenie ogólniejsze - także dla (obecnie zdecydowanie niesatysfakcjonującego) sposobu uprawiania nauk społecznych w Polsce.

\section{Wiejskość jako aktywny kontekst ogólnych procesów}

Wiele zjawisk podejmowanych przez badaczy wsi i rolnictwa (uczestnictwo w kulturze, religijność, poziom kapitału społecznego, struktura społeczno-zawodowa, bezrobocie, migracje zarobkowe) wykazuje na tyle daleko posuniętą specyfikę oraz odmienność w sposobie przekształcania się, że uzasadnia to poszukiwanie w kontekście wiejskim czegoś więcej niż tylko neutralnych ram dla przebiegających tam procesów. Innymi słowy, wydaje się zasadne dostrzeganie w „wiejskości”, obojętnie jak rozumianej, pewnego rodzaju zmiennej niezależnej, która warunkuje mniej lub bardziej odmienny kształt zachodzących tam przemian o charakterze ogólnym i powszechnym, a więc - mogłoby się zdawać - bardzo podobnych, jeśli nie takich samych. Dobrym przykładem pozwalającym zakwestionować utarte schematy myślenia o zmianie społecznej może być monografia Anny Olszewskiej Wieś uprzemysłowiona. Studium to potwierdza znaczenie układów lokalnych jako aktywnego czynnika, który istotnie modyfikuje oddziaływanie zewnętrznych prawidłowości. Dobrzeń Wielki, położona niedaleko Opola wieś rolnicza, poddawana była już od połowy XIX wieku intensywnym procesom migracji, uprzemysłowienia i urbanizacji, ale wcale nie stanowiła znanego z podręczników modelowego przykładu modernizacji. Chociaż od dawna powiązana z przemysłem przez praktykowane na dużą skalę dojazdy do pracy w okolicznych większych ośrodkach (zjawisko chłopo-robotnictwa) i pozarolnicze zarobkowanie na miejscu w fabryce dziewiarskiej, chociaż

wyglądem zewnętrznym i wielkością zbliżona do miasteczka, a trybem życia i sposobem ubierania się podobna do miasta, pod wieloma względami - jak pisze autorka - zachowała cechy wsi tradycyjnej, izolowanej od szerszej zbiorowości, 
żyjącej swoim własnym życiem, poddanej panowaniu i ocenie kilku nielicznych osób, uznawanych w społecznej opinii wsi za szacowne i jedynie do tego upoważnione (Olszewska 1969, s. 122).

Wprawdzie nowe instytucje i urządzenia pojawiające się we wsi (takie jak zakład pracy czy telewizja) wywierały wpływ na tryb życia jej mieszkańców, to jednocześnie bardzo wyraźnie zostały podporządkowane obowiązującemu tam systemowi wartości. Badaczka odnotowała na przykład zjawisko oddziaływania lokalnej opinii na decyzje dyrektora fabryki w sprawie zatrudnienia czy też w sferze moralno-obyczajowej, jak też fakt, że młode robotnice, które podejmowały tam pracę, będąc już finansowo samodzielne, nadal pozostawały pod wpływem i kontrolą grupy rodzinno-sąsiedzkiej. Również telewizja, aczkolwiek niewątpliwie umożliwiała mieszkańcom Dobrzenia Wielkiego bliższy kontakt z kulturą, zwłaszcza masową, nie spowodowała zasadniczej zmiany w ich postawach. Stało się tak dlatego, że „telewizji została wyznaczona pewna społeczna rola: dostarczania rozrywki w ramach dotychczasowego trybu życia. Telewizja została podporządkowana już istniejącemu trybowi życia, nie zmieniła go w jakiś wyraźny sposób”. To szczególnego rodzaju włączenie nowego medium do życia społeczności lokalnej uwidaczniało się między innymi w stosunku audytorium do emitowanych treści. Obserwowane w programach telewizyjnych

wzory postępowania, normy, oceny, propozycje, reguły obyczajowe spotykają się z żywą reakcją, jeżeli korespondują z treściami, wzorami znanymi mniej więcej w życiu rodziny lub wsi jako społeczności. Inne, odbiegające od nich, traktowane są jako „dziejące się w innym świecie”, dotyczące innych ludzi. Traktowane są jako sensacyjne lub takie, o których można wiedzieć, nie przyjmując ich jako obowiązujące dla siebie (Olszewska 1969, s. 145).

Skoro zatem społeczność lokalna wyznaczała interpretację nadawanych treści, tym samym pokazała, że jest w mocy jedne z nich czynić istotnymi, a pozostałe „unieważniać”, immunizując się niejako na ich ewentualne oddziaływanie. Można więc odnieść wrażenie, że nowe instytucje i treści zostały oswojone i w pewnym sensie wchłonięte przez tradycyjny kontekst i dotychczasowy sposób życia, podporządkowane mu i sfunkcjonalizowane względem jego wymogów. W rezultacie, mimo krzyżowania się tak różnorodnych wpływów, nie odnotowano w Dobrzeniu zjawiska dysharmonii kulturowej, ścierania się sprzecznych orientacji czy konfliktu pokoleń. Wnikliwa, bo dokonana metodą monograficzną, analiza społeczności lokalnej pozwoliła autorce podważyć hipotezę przypisującą decydujące znaczenie w powojennych przemianach polskiej wsi zjawiskom industrializacji oraz urbanizacji, a nawet 
zarysować jako co najmniej równie prawdopodobną hipotezę odwrotną: o zasadniczej roli kontekstu lokalnego i tradycyjnej kultury w kształtowaniu współczesnego oblicza środowisk wiejskich. W takim ujęciu „wiejskość”, rozumiana jako szczególny typ społeczności lokalnej, staje się właśnie ową zmienną niezależną, która istotnie modyfikuje kształt dobrze wydawałoby się znanych procesów, a przez to stanowi nieocenione laboratorium dla badania różnych wersji modernizacji. Wniosek ten pozostaje również w zgodzie z tezą sformułowaną przez Antoniego Komenderę, który analizując zalety metody monograficznej, podkreślał, że jej szczególnym walorem pozostaje zdolność nie tyle potwierdzania, czyli weryfikowania ogólnie uznanych twierdzeń, ale właśnie możliwość ich falsyfikowania, a więc podważania lub nawet obalania powszechnie przyjętych w nauce generalizacji (Komendera 1973). W tej okazji do uczenia badaczy „nieposłuszeństwa w myśleniu” i budzenia ich nonkonformizmu kryje się zatem ogromny potencjał metody dziś często lekceważonej i zapomnianej: daje ona bowiem szansę na formułowanie nowych teorii i budowanie nowych paradygmatów badawczych zamiast odwoływania się do tych zastanych i mocno już wyeksploatowanych.

\section{Pożytki z interdyscyplinarności}

Także stosowanie podejścia interdyscyplinarnego, niezbędne w odniesieniu do problematyki wsi i rolnictwa, sprzyja odkrywaniu nowych zależności i formułowaniu śmiałych hipotez. Przykładem może tu być temat tradycyjnego chłopskiego gospodarowania, które w świetle klasycznych teorii ekonomicznych wydaje się anachroniczne, pozbawione logiki i skrajnie nieefektywne. Dzieje się tak dlatego, że ekonomia zajmuje się przede wszystkim zjawiskami produkcji i wymiany zachodzącymi w kontekście wolnego rynku podporządkowanego regułom konkurencji, natomiast badanie gospodarki chłopskiej wymaga uwzględnienia także czynników kulturowych, społecznych, a nawet biologicznych. W pierwszym tomie dzieła Chłop polski w Europie i Ameryce William Thomas i Florian Znaniecki zarysowali rozległą panoramę „starej ekonomii rodzinnej”, która określała zasady rządzące tą sferą życia. Zgodnie z tymi zasadami należy wyróżnić nie jedną, ale trzy kategorie własności (ziemię, trwałe produkty ludzkiej działalności i pieniądze, czyli dochód). Co szczególnie ważne, żadna z nich nie jest odpowiednikiem „kapitału” czy tym bardziej „towaru” w ścisłym rozumieniu tego słowa, jak chcieliby tego ekonomiści. Przykładowo, ziemia jest zasadniczo własnością całej rodziny nie tylko w sensie synchronicznym, ale i diachronicznym (to zarówno „ojcowizna”, jak i - aby posłużyć się neologizmem Gombrowicza - „synowizna”), stanowi więc „międzypokoleniowy depozyt" i jednostka nie może dysponować nią w pełni swobodnie. Podobnie nietypowo przedstawia się sprawa $\mathrm{z}$ drugim czynnikiem produkcji, czyli z pracą. 
Tutaj również da się dostrzec wpływ szczególnych, kulturowych i społecznych reguł, które zgodnie z zasadami „stałej solidarności wiążącej rodzinę” wymagają, by na rzecz gospodarstwa pracował każdy, w miarę potrzeb i swoich możliwości. Ta zaś norma oznacza, że „wkład pracy nie upoważnia nikogo do upominania się o zapłatę” - jak tłumaczył Znaniecki - ale też „niezdolność do pracy nie może uszczuplić niczyich praw gwarantujących utrzymanie z gospodarstwa rodzinnego" (Thomas, Znaniecki 1976, s. 144).

Ekonomiści, opisując te specyficzne cechy chłopskiej pracy, charakteryzowali je w swoim języku jako: „nieprzesuwalność” (bo zasadniczo umiejętności członka rodziny dawały się wykorzystać tylko w obrębie jego zagrody), , ,autoeksploatację" (zwłaszcza w okresie spiętrzenia robót) lub „podprodukcję” (w przypadku, gdy obowiązków było mniej). Tym jednak, co wydawało się z ich punktu widzenia najbardziej absurdalne, były liczone w kategoriach „zysku” wyniki tej pracy. Jeżeli zakładano, co czynił np. szwajcarski badacz Ernest Laur, że rodzinne gospodarstwo chłopskie trzeba analizować analogicznie jak przedsiębiorstwo kapitalistyczne, okazywało się, że wartość dochodu uzyskiwana w takim gospodarstwie jest ujemna. $\mathrm{Na}$ wadliwość rozumowania wiążącego się $\mathrm{z}$ takim założeniem niejednokrotnie zwracali uwagę historycy gospodarczy (Kula 1962; Kochanowicz 1992) oraz antropologowie gospodarki (Romaniszyn 1994; Krzyworzeka 2014), podkreślając, że nieuzasadnione jest stosowanie logiki rynkowej w odniesieniu do funkcjonującego według zupełnie innych zasad wiejskiego gospodarstwa rodzinnego. Teorię tłumaczącą odrębność i swoistą racjonalność gospodarki chłopskiej przedstawił już w latach 20. ubiegłego wieku rosyjski badacz, Aleksander Chajanow. Za czynnik najważniejszy uznał on cykl biologiczny rodziny, która w miarę przychodzenia na świat kolejnych dzieci obciąża się początkowo coraz większą liczbą konsumentów, ale jednocześnie wraz z upływem lat dysponuje zwiększającą się liczbą producentów. Ponieważ celem podejmowanych przez rodzinę chłopską wysiłków jest przeżycie, a nie - jak w przypadku przedsiębiorcy kapitalistycznego - bogacenie się, najważniejsze okazuje się sprostanie wymogom samozaopatrzenia, sprzedaż zaś nadwyżki produktów na rynku stanowi zaledwie margines całej aktywności. Rozwinięciem koncepcji Chajanowa, ale i polemiką z nią, jest teoria współzależności rozwoju rodziny chłopskiej i chłopskiego gospodarstwa sformułowana zaraz po II wojnie światowej przez Wincentego Stysia. Uczony ten pokazał, jak równolegle do etapów życia i liczebności rodziny następują kolejne etapy i powiększanie się (w wyniku narodzin dzieci) bądź zmniejszanie (wskutek odchodzenia „na swoje” dorosłych już dzieci, z których każde trzeba odpowiednio wyposażyć) rozmiarów jej gospodarki (Styś 1959). W jego ujęciu rodzina chłopska i jej gospodarstwo pozostawały w ścisłym, organicznym związku, dla którego objaśnienia bardziej przydatny jest sugerowany przez Oswalda Spenglera (Spengler 2001) „takt fizjonomiczny” niż 
abstrakcyjne modele ekonomiczne, krytykowane już przez Alexisa de Tocqueville (Tocqueville 1994).

Przywołane przykłady pokazują, że w badaniu wiejskiej rzeczywistości niezbędne jest łączenie podejść właściwych różnym dyscyplinom naukowym, gdyż poprzestawanie na aparaturze i dorobku wypracowanym tylko przez jedną z nich prowadzi do niezrozumienia sposobu funkcjonowania świata wiejskiego. Świadomość tego wydaje się rzeczą ważną z kilku powodów. Przede wszystkim dlatego, że charakterystyczny dla chłopstwa kształt życia i pracy wciąż dotyczy znacznej części mieszkańców globu, przy czym nie chodzi tu bynajmniej o zjawiska marginalne, reliktowe czy anomalie. Jeszcze w drugiej połowie XX w. Witold Kula podkreślał, że problem ten staje się palący, gdyż w dzisiejszym świecie

większość ludzkości to ludność krajów „zacofanych”, zaś większość ludności krajów „zacofanych” żyje właśnie w drobnych, słabo z rynkiem powiązanych, a głównie na własne potrzeby konsumpcyjne pracujących rodzinnych gospodarstwach chłopskich. Samowystarczalne gospodarstwo chłopskie jest więc niewątpliwie najliczniejszą dziś na świecie formą organizacyjną działalności produkcyjnej (Kula 1962, s. 42).

Trudno przyjąć, by po upływie pół wieku z okładem sytuacja zmieniła się diametralnie. I faktycznie się nie zmieniła: Ladislau Dowbor przypomina, że już w XXI w. „nadal połowa ludności świata żyje na wsi”, a w takiej np. Brazylii „rolnictwo nadal daje zatrudnienie największej ilości pracowników, 17 milionom, przemysł 9 milionom, handel około 7" (Dowbor 2017, s. 234). Co więcej, w dzisiejszym świecie rolnictwo coraz śmielej wkracza do miast, niekoniecznie tych małych, ale właśnie największych. Kacper Pobłocki przywołuje wyliczenia, z których wynika, że obecnie 800 mln mieszkańców miast (a więc około 1/4 wszystkich) trudni się rolnictwem - $60 \%$ powierzchni Bangkoku i 1/3 Szanghaju oraz 8\% Londynu przeznaczone jest pod uprawę i zauważa: „ruralizacja tych miast nie jest symptomem zacofania; nawet hipernowoczesny Hongkong sam wytwarza dwie trzecie konsumowanego w mieście drobiu, jedną szóstą wieprzowiny i połowę warzyw" (Pobłocki 2017, s. 92-93). Stanowczo, należałoby zatem poddać rewizji obowiązujący paradygmat modernizacji i wyobrażenia o tym, co wiejskie, a co „zurbanizowane". Z wymogiem wnikliwego śledzenia zjawisk tego rodzaju związane są jednak nie tylko względy praktyczne, ale również naukowe, bo istnienie tak szczególnych i niezmiernie trwałych form gospodarowania pociąga za sobą konieczność stałego rozwijania warsztatu badawczego i gotowość do podważania zastanych paradygmatów. Jak pokazały przywołane przykłady, dopiero odwołanie się do interpretacji kulturowych, społecznych, a nawet biologicznych pozwala prawidłowo uchwycić 
specyfikę chłopskiego sposobu gospodarowania - tego fundamentu całego „segmentu agrarnego" - a tym samym zakwestionować wpływowe, choć jednostronne teorie, które fałszywie naświetlając dany przedmiot (bo narzucając tylko jedną obowiązującą interpretację), przyczyniają się jednocześnie do jego niezrozumienia, a w konsekwencji także do deprecjonowania.

\section{Antyruralizm i jego konsekwencje}

Tymczasem dowodów na uporczywe trwanie wielu stereotypowych i krzywdzących przekonań na temat wsi i rolnictwa nie brakuje. Zakorzenione są one zarówno w myśleniu potocznym (na „miejski szowinizm” zwracał uwagę Andreas Bodenstedt [1998]), jak i w zdecydowanie antyruralistycznym nastawieniu nauk społecznych (Poleszczuk 1990), w tym - paradoksalnie - także samej socjologii wsi (co wyraża się chociażby w obowiązujących schematach zmiany społecznej, które to, co wiejskie z reguły sytuują w przeszłości, przyszłość zaś wiążą z dominacją miast), w kolejnych ideologicznych opcjach (najpierw w zdecydowanie antychłopskiej ortodoksji marksistowskiej, a później w nie mniej antychłopskim neoliberalnym fundamentalizmie) czy wreszcie w wyraźnych, zwłaszcza w Polsce, poststanowych uprzedzeniach i stereotypach. We wszystkich tych kontekstach tematyka wiejska jest uważana za mało ważną, bo dotyczącą zjawisk postrzeganych jako zaprzeczenie postępu i nowoczesności, co pociąga za sobą to, że w rolnictwie widzi się zdecydowanie marginalną i niedochodową gałąź gospodarki, a mieszkańców wsi uznaje się za balast podejmowanych każdorazowo przemian modernizacyjnych.

Utrwaleniu takich niekorzystnych opinii służą konkretne praktyki dyskursywne, znajdujące swoje egzemplifikacje nie tylko w debacie publicznej, ale i w tekstach naukowych sygnowanych nazwiskami najbardziej uznanych przedstawicieli socjologii czy ekonomii (dyskurs „hegemoniczny” - analizowany przez Annę Malewską-Szałygin, procedury „orientalizowania” - opisane przez Michała Buchowskiego, kategoria „urasowienia” - badana przez Monikę Bobako) (Buchowski 2008; Bobako 2010; Malewska-Szałygin, Rakowski 2011). Wspólnym mianownikiem tych wszystkich zabiegów jest dążenie do nadania „brudnego znaczenia” określonej grupie ludzi po to, by przez zdefiniowanie ich jako mniej wartościowych, uzasadnić ich niepowodzenia oraz gorsze traktowanie. Tego rodzaju strategie mają jednak swoją drugą stronę: piętnowanie pewnych grup społecznych za pomocą znamiennych epitetów (w polskim dyskursie transformacyjnym rolę tę pełniły często stosowane określenia: „wyuczona bezradność”, „roszczeniowość”, „brak kompetencji cywilizacyjnej” czy „klasy złodziejsko-żebracze”) demaskuje nader niekorzystne charakterystyki przede wszystkim tych, którzy używają danego języka. Jak pisał bowiem Teodor Adorno w swoim klasycznym dziele Osobowość autorytarna: 
wszystkie te wątki należą do tradycyjnych mądrości skrajnego ekonomicznego indywidualizmu i są akcentowane przez wszystkich ludzi, którzy uważają, że systemowi liberalnemu zagraża socjalizm. Zarazem koncepcje te mają nieco sadystyczne i autorytarne zabarwienie, co czyni je idealnymi przekaźnikami niektórych typowych impulsów psychologicznych uprzedzonej osobowości. Człowiek o osobowości potencjalnie faszystowskiej oskarża ubogich, którzy potrzebują wsparcia, o pasywność i roszczeniowość, której nauczył się nie dopuszczać do własnej świadomości (Adorno 2010, s. 240-241).

Założenia stanowiące przesłankę twierdzeń, które składają się na wspomniany wyżej neoliberalny dyskurs rasistowski, można zakwestionować, wszelako pod warunkiem należycie wnikliwego i pozbawionego uprzedzeń badania problemów wsi i rolnictwa. Za przykład może tu służyć mechanizm nazywany przez ekonomistów „przepływami międzygałęziowymi”: jego prawidłowe rozpoznanie obala często powtarzane przeświadczenie, iż rolnictwo jest szczególnie zacofaną, niewydolną gałęzią gospodarki. W perspektywie doświadczeń polskich, które jednak - co pokazuje w swojej książce Skok w nowoczesność Adam Leszczyński - nie były jakimś szczególnym przypadkiem, a raczej dość typową dla krajów peryferyjnych strategią modernizacyjną (Leszczyński 2013), widać bowiem, że to właśnie tak krytykowany segment agrarny, a zwłaszcza jego chłopska część, okazywały się jeśli nie jedynym, to na pewno najdogodniejszym zasobem akumulacji pierwotnej. Począwszy od ponownego wprowadzenia pańszczyzny w XV w., przez reformy pouwłaszczeniowe, rozbudowę okręgów przemysłowych w II RP, intensywną industrializację po II wojnie światowej, wreszcie transformację w III RP, jednym słowem - za każdym razem, kiedy rozważano możliwości dopasowania Polski do aktualnego porządku światowego, wpisania jej w międzynarodowy podział pracy tudzież dokonania znaczącego skoku modernizacyjnego kraju - źródłem, z którego dawało się czerpać niezbędne po temu środki, była wieś i rolnictwo. Sięgano tam po możliwie tanio bo często pod przymusem - przejmowane zasoby materialne (żywność, surowce), pieniądze ( $w$ formie zwiększonego obciążenia podatkowego) oraz kapitał ludzki (siła robocza czerpana z rolnictwa indywidualnego stanowiła istotny wkład migracyjny w rozwój kraju, ale zarazem oznaczała drenaż wiejskiego kapitału ludzkiego). Tylko w latach 1950-1955 polskie rolnictwo wytwarzało rocznie średnio 33\% dochodu narodowego, ale konsumowało zaledwie 11\% (Łopato 1988, s. 149). Z kolei przeprowadzone dla lat $1965-1968$ obliczenia dowodziły, że prawie $1 / 4$ produkcji czystej rolnictwa była realizowana poza tym sektorem, a po roku $1989 \mathrm{w}$ dalszym ciągu niemal 25\% dochodu wypracowanego w rolnictwie przechwytywały inne sektory gospodarki (Woś 2001). Te właśnie długotrwałe i skrajnie asymetryczne „przepływy międzygałęziowe”, nie zaś jakieś wydumane immanentne „słabości” 
segmentu agrarnego, powodowały osłabianie sił produkcyjnych rolnictwa oraz pogarszanie warunków życia ludności wiejskiej, Ponieważ jednak ten systematycznie uprawiany, nieraz bardzo brutalny drenaż wsi i rolnictwa prowadził do ich dewastowania, ale z drugiej strony nie przyczyniał się do trwałego rozwoju całego kraju, Jacek Kochanowicz słusznie określał tę niepokojącą prawidłowość mianem polskiego paradoksu modernizacyjnego (Kochanowicz 1992).

Scharakteryzowana tu prawidłowość może posłużyć za jeden z wielu punktów oparcia dla sformułowania tezy zaprzeczającej najczęściej wygłaszanym sądom: o marginalnej roli wsi i rolnictwa w Polsce, o jakichś szczególnych deficytach charakteryzujących ludność wiejską czy też o negatywnym piętnie, jakie dziedzictwo chłopskie odciska na współczesnym społeczeństwie. Przeciwwagą dla tych wszystkich antyruralistycznych twierdzeń jest określenie użyte przez Krystynę Szafraniec, która segment agrarny nazwała "polskim residuum systemowym” (Szafraniec 2002). Jak się wydaje, diagnoza ta broni się pod każdym względem, zwłaszcza jeśli przypisać jej pozytywne konotacje. Broni się więc, jeśli chodzi o dane ilościowe ( $w$ Polsce obszary wiejskie to wciąż ponad $90 \%$ powierzchni kraju, a do połowy XX w. mieszkańcy wsi stanowili przeważającą większość ogółu ludności kraju: według spisu powszechnego z 1931 r. aż 73\% Polaków mieszkało na terenach wiejskich; obecnie ich liczba sięga niemal 40\%). Broni się także jako charakterystyczna cecha procesów zachodzących w tym okresie (polskie rolnictwo wciąż zapewnia krajowi samowystarczalność żywnościową, stanowi najważniejszą pozycję w eksporcie i absorbuje znaczną część siły roboczej - od 2000 r. nawet zwiększa się udział zatrudnionych w tym sektorze w stosunku do ogółu pracowników; podobnie przedstawia się sytuacja ludnościowa wsi: wprawdzie przez cały okres powojenny jej liczba malała znacząco w ujęciu procentowym: z 66\% w $1946 \mathrm{r}$. do $38,1 \%$ w 1995, ale realnie spadła zaledwie o niespełna 900 tys., czyli tyle co nic: z 15597 tys. do 14724 tys., natomiast od 2000 r. rośnie systematycznie!). Broni się wreszcie jako charakterystyka jakościowa (już w latach 70. Andrzej Sadowski zdiagnozował, że w Polsce dokonuje się nie tylko urbanizacja i industrializacja, ale też wielowymiarowa ruralizacja, czyli „wsiowienie”; z kolei u schyłku PRL-u Jacek Wasilewski określił polskie społeczeństwo jako „chłopskie” - pod względem demograficznym, mentalnym i kulturowym; Wasilewski 1986; Sadowski 1994).

Aby w pełni docenić znaczenie obszarów wiejskich, nie wolno też zapominać o sprawach bardziej doraźnych i praktycznych: w Polsce to elektorat wiejski przesądza o wynikach wyborów, a więc dobre rozpoznanie tego fragmentu rzeczywistości ma również swój aspekt polityczny. Natomiast z najpoważniejszym bodaj i najczęściej powtarzanym w minionych latach zarzutem wysuwanym pod adresem polskiej wsi - że stanowi ona balast rozwojowy dla całego kraju - rozprawił się już dawno temu Jan Szczepański, przypisując jej bardzo cenną rolę „moderatora” każdorazowo 
wprowadzanych zmian (Szczepański 1971). Tę myśl rozwinął po latach Jerzy Wilkin, pisząc o roli chłopstwa, że „w procesach dziejowych chłop jest zazwyczaj mało widocznym i nieefektywnym aktorem, pozostaje on w cieniu i ciszy, ale skutki jego długotrwałego i żmudnego działania są na ogół większe niż badacze historii społeczeństw skłonni są mu przyznać" (Wilkin 1988, s. 22). Warto tu nadmienić, że do podobnej argumentacji odwoływali się już w XIX w. działacze i publicyści obozu narodowego, dążący do upodmiotowienia warstw ludowych i uczynienia z nich siły politycznej. Jak przypomina Anna Karczewska, wedle ideologów endeckich „chłopi, nawet nie podejmując żadnych działań, pozostając biernym elementem tkanki społecznej przez sam instynkt przetrwania mieli moc wpływania na przebieg wypadków dziejowych" (Karczewska 2017, s. 244).

Jak się wydaje, takie opinie zarysowują pożądaną, bo przeciwstawną wobec „monumentalnej” i „zdarzeniowej”, wizję dziejów danego społeczeństwa (opartą na założeniu aktywizmu wybitnych jednostek i ich w pełni świadomych decyzji, artykułowanych następnie w tekstach wpisywanych w kanon kultury narodowej). W konkurencyjnym wobec niej ujęciu równie ważne, jeśli nie ważniejsze, wydają się bowiem działania drobne, rozciągnięte $\mathrm{w}$ czasie, a nawet samo bierne trwanie lub stawianie oporu, niekoniecznie będące wynikiem świadomej refleksji czy ujęte w przekonujące narracje. Obraz dziejów ujęty w zasadzie Giambattisto Vico homo intelligendo fit omnia właśnie w odniesieniu do polskiego społeczeństwa, z jego utrzymującą się przez wieki dwoistą strukturą społeczną i jej wielorakimi konsekwencjami, domaga się więc zbudowania silnej alternatywy w postaci wizji wykorzystującej drugą ze wspomnianych przez Vico zasad: homo non intelligendo fit omnia. O ile głównym bohaterem tej pierwszej byliby członkowie elity („panowie"), to podmiotem tej drugiej pozostawaliby chłopi („warstwa kmieca”) - zgodnie zresztą ze znanym rozróżnieniem Antoniego Kępińskiego, który dał następującą charakterystykę dwu polskich charakterów narodowych. Pierwszy typ, nazwany przez niego "histerycznym”, to typ szlachecki: polskie „zastaw się, a postaw się", polonez, Samosierra, szarża ułanów na czołgi, polskie sejmikowanie, liberum veto i polnische Wirtschaft. Drugi typ, „psychasteniczny”, to typ plebejski, ludowy - polskiego kmiecia, który jest cichy, spokojny, pracowity, nie wadzi nikomu i cierpliwie znosi wiele przeciwności, ale doprowadzony do ostateczności potrafi pokazać swój „steniczny kolec”, a wówczas poczciwy kmiotek przeraża krwawym widmem Jakuba Szeli (Kępiński 1992, s. 91-92).

Również współczesna myśl społeczna dostrzega atrybuty podmiotowości i sprawstwa nie tylko w działaniach aktywnych, ale też w samym istnieniu określonych grup i w ich ministrategiach, które mogą wydawać się tylko sposobami na przetrwanie, lecz w rzeczywistości mają dalekosiężne i doniosłe skutki. Kierując się taką intuicją, David Levine stara się zerwać z przekonaniem o wyłącznie pasywnej 
roli rodziny chłopskiej i przypisuje jej istotną funkcję w ekspansji imperium brytyjskiego: „proces reprodukcji rodzin leży w samym sercu mojej argumentacji, pozwala on bowiem uchwycić jedną z najbardziej rewolucyjnych sił w historii Anglii - cichą, skumulowaną presję wywieraną przez żyjących na krawędzi przeżycia chłopów" (Levine 1987, s. 5). Podobnie czyni Margaret Archer, dla której „najważniejszym aspektem sprawstwa jest zdolność do «czynienia różnicy» w społeczeństwie”, przy czym autorka dodaje:

nie sądzę, że z konieczności zakłada to aktywność, w szczególności, jeśli ta ostatnia oznacza umiejętność „postąpienia inaczej”. Mam tu na myśli zbiorowości, których efekty przynosi ich sama obecność. To raczej ich „istnienie” niż „działanie” ma charakter przyczynowy, ponieważ rodzi konsekwencje” (Archer 2013, s. XX).

W dziejach polskiego społeczeństwa chłopstwo było niewątpliwie takim właśnie niedocenianym, a ważnym czynnikiem zarówno trwania, jak i zmiany. Refleksja na ten temat, czerpiąca wiele $\mathrm{z}$ dorobku polskiej socjologii wsi, mogłaby się przyczynić do nadania nowego kierunku badaniom nad tematami ogólniejszymi, a wciąż atrakcyjnymi poznawczo, takimi właśnie jak podmiotowość, sprawstwo czy działanie społeczne.

Aby zdobyć się na podważenie utartych schematów myślenia i podanie w wątpliwość utartych schematów oraz zaproponowanie nowych podejść, niezbędna jest jednak dobra znajomość problematyki wsi i rolnictwa oraz klasycznych tekstów z tego zakresu, co wśród szerokiego grona badaczy społecznych (o ile nie obrali sobie za przedmiot analiz właśnie tej dziedziny rzeczywistości) nie jest rzeczą często spotykaną. Na ten fakt wpłynęło wiele czynników. Przede wszystkim należy tu wymienić wskazaną już wcześniej poststanową mentalność całego polskiego społeczeństwa, w tym także jego elit, które - zapominając o diagnozie Józefa Chałasińskiego, że swoją genezę zawdzięczają nie społecznemu awansowi, lecz procesowi degradacji (Chałasiński 1995), wciąż przejawiają skłonność do przypisywania sobie przewodniej roli w społeczeństwie oraz decydującego głosu w budowaniu narracji historycznych. Skutkiem tego wizja dziejów Polski, obraz polskiego społeczeństwa oraz obowiązująca hierarchia wartości są zdominowane przez perspektywę szlachecko-inteligencką z właściwą jej orientacją na tradycje insurekcyjne, czyny zbrojne i zrywy niepodległościowe realizowane nawet kosztem naruszenia substancji biologicznej narodu, natomiast praktycznie nieobecna jest optyka, która doceniałaby wkład innych warstw, doniosłość ich mniej efektownej, ale efektywnej pracy organicznej oraz działań ciągłych, których rezultaty są widoczne dopiero w dłuższej perspektywie. O historię pisaną z perspektywy najliczniejszej 
grupy społecznej, czyli chłopów, upominał się już przed laty Karol Modzelewski (Modzelewski 1987); ostatnio podobne postulaty formułuje Andrzej Leder, zarysowując projekt jeszcze nienapisanej epopei chłopskiej emancypacji (Leder 2017).

\section{Badanie wsi i rolnictwa a kondycja nauk społecznych w Polsce}

Opisane tu pokrótce antyruralistyczne nastawienie owocuje jednak nie tylko konkretnymi krzywdzącymi diagnozami czy niebezpiecznymi i nasuwającymi oczywiste skojarzenia postulatami (w rodzaju „emigracji ostatniej” zakładającej opuszczenie kraju przez 2,5-3 mln uznanych za „zbędnych” mieszkańców wsi) (Grabowska-Lusińska, Okólski 2009), ale też przejawia się w kształcie uprawianych w Polsce nauk społecznych. Panuje przekonanie, że ich kondycja, mierzona chociażby pozycją w międzynarodowych rankingach, jest słaba, a jedną ze wskazywanych przyczyn ma być (pół)peryferyjne usytuowanie w światowym polu akademickim dyscyplin takich jak socjologia, politologia czy ekonomia. Badacze zajmujący się tą kwestią podkreślają zwłaszcza znamienny i asymetryczny „podział pracy” między ośrodkami usytuowanymi w centrum, a tymi położonymi na bliższych bądź dalszych peryferiach: o ile $\mathrm{w}$ tych pierwszych są formułowane nowe propozycje teoretyczne, to tym drugim przypada z reguły rola podwykonawców, produkujących co najwyżej case studies. „Do opracowywania studiów przypadków «weryfikujących» teorie z centrum sprowadza się też rola większości naukowców społecznych z regionów i krajów peryferyjnych, którzy uczestniczą we wspólnych projektach badawczych" - zauważa Tomasz Zarycki (2009, s. 111). Taka pozycja jest m.in. skutkiem polityki prowadzonej przez resort nauki, który - zdaniem Tomasza Warczoka i Tomasza Zaryckiego - narzucając określone zasady parametryzacji, przydzielając punktację czasopismom i naciskając na publikowanie w języku angielskim, de facto "legitymizuje lokalnie hierarchię globalną, uprawomocnia i naturalizuje centro-peryferyjny podział pola naukowego", co „tylko w ograniczonym stopniu prowadzić może do realnego wejścia w do globalnej gry" (Warczok, Zarycki 2016, s. 168).

Taka pozycja wynika też jednak z działania polskich elit akademickich na rzecz umacniania autorytetu najpierw wschodnich, a obecnie zachodnich ośrodków (co ma niejednokrotnie podłoże czysto materialne - zauważa Daniel Płatek [2016, s. 197]). Dokonuje się to przez kolportowanie na polskim gruncie i narzucanie własnemu środowisku koncepcji wytworzonych za granicą jako teorii rzekomo najlepszych i powszechnie obowiązujących, a więc zarazem - jako najodpowiedniejszych schematów wyjaśniania i oceniania polskiego społeczeństwa. Znamienne, że tego typu postawa bywa jednak kontestowana przez prominentnych przedstawicieli zachodniej nauki: przykładem znana polemika Michaela Burawoya z Piotrem Sztompką, gdzie - paradoksalnie - wybitny badacz z jednego 
z najlepszych uniwersytetów na świecie dostrzegał wady i ograniczenia amerykańskiej socjologii wychwalanej bezkrytycznie przez profesora zatrudnionego na jednej z peryferyjnych uczelni, która w dodatku zajmuje bardzo odległe miejsca na liście szanghajskiej (Burawoy 2011; Sztompka 2011). Istnieniem takich właśnie mechanizmów, dzięki którym elity intelektualne w pełni zasługują na miano elit kompradorskich, Ewa Domańska tłumaczy „impotencję polskich badaczy do tworzenia własnych ujęć teoretycznych” i przestrzega: „traktując wytworzone w Europie Zachodniej i USA teorie jako gotowe do użycia skrzynki z narzędziami dokonujemy intelektualnej autokolonizacji, sami się prowincjonalizujemy" (Domańska 2012, s. 158). Na groźbę utraty „intelektualnej suwerenności” zwraca uwagę także Krystyna Romaniszyn (Romaniszyn 2013, s. 61). Wszystkie tego typu obserwacje trzeba potraktować jako sygnały utrwalania się niebezpiecznego kierunku w aktualnym rozwoju nauki w Polsce, a jednym ze środków przeciwdziałania tej tendencji może być właśnie rzetelne i pozbawione kompleksów badanie wsi i rolnictwa.

Za taką sugestią przemawia przede wszystkim wskazana wcześniej prawidłowość, która pozwala dostrzec w kontekście wiejskim czynnik istotnie modyfikujący ogólne procesy; to zaś uzasadnia przypuszczenie, że ich opis dokonany na gruncie zachodnim niekoniecznie musi być uznany za powszechnie obowiązujący; z tego można $\mathrm{z}$ kolei wyprowadzić wniosek, że możliwe byłoby sformułowanie teorii oryginalnych i niezależnych od już istniejących, bo ugruntowanych na odmiennej rzeczywistości. Za taką sugestią przemawia też omówiony wyżej wymóg interdyscyplinarnego traktowania problematyki wsi i rolnictwa, gdyż dopiero triangulacja różnych podejść, metod i koncepcji pozwala na właściwe zrozumienie wielu występujących tam zjawisk, które analizowane za pomocą rzekomo uniwersalnych schematów tylko jednej z dyscyplin, okazują się niewystarczające, jeśli nie wręcz fałszywe. Do takiego przekonania skłania wreszcie fakt, że właśnie w badaniach polskiej wsi i rolnictwa odnotowano szereg osiągnięć prekursorskich, wyprzedzających o kilka dziesięcioleci ustalenia nauki zachodniej. Dość wspomnieć tu o „pionierskim osiągnięciu w dziedzinie demografii historycznej”, za jakie Etsuo Yoshino uważa Żmiącą Franciszka Bujaka, napisaną pół wieku przed publikacjami Phillippe’a Ariesa (Yoshino 1997, s. 9). Warto też wymienić monografię Krystyny Dudy-Dziewierz Wieś małopolska a emigracja amerykańska z 1938 r., gdzie polska badaczka opisała specyficzne cechy migrowania z peryferii do centrum „odkryte" ponownie dopiero w latach 80. przez Odeda Starka (Duda-Dziewierz 1938). Należy również pamiętać o tym, że to Józef Chałasiński w swoim Młodym pokoleniu chłopów dużo wcześniej niż Pierre Bourdieu zwrócił uwagę na dwuznaczną rolę szkoły wobec środowiska wiejskiego i uczniów pochodzących z „klas ludowych” (Chałasiński 1984), a Kazimiera Zawistowicz-Adamska na pół wieku przed Kirsten 
Hastrup zrealizowała zamysł „antropologii doświadczenia”, pisząc w 1948 r. swoją Społeczność wiejską (Zawistowicz-Adamska 1948).

Wielka szkoda, że te fakty nie są powszechnie znane i nie inspirują kolejnych pokoleń naukowców do własnych niezależnych poszukiwań. Częściową, ale ważną przyczyną takiego stanu rzeczy jest niewątpliwie obecny kształt edukacji akademickiej, gdzie kładzie się nacisk na zapoznawanie studentów z najnowszymi tendencjami w nauce światowej, kompletnie zaniedbując udostępnianie im wcześniejszego dorobku rodzimych badaczy. Drobnym, ale znamiennym przykładem może być nieobecność regularnych kursów z zakresu socjologii wsi w wielu, nawet najlepszych jednostkach akademickich kraju (Bukraba-Rylska 2012). Trudno zatem dziwić się, że w takiej sytuacji polscy badacze pracowicie i z dużym nakładem kosztów przyswajają sobie dorobek autorów zagranicznych, a następnie próbują wygłaszać referaty i publikować za granicą, co sprowadza się do tego, że relacjonują kolegom z Zachodu to, co tamci i tak znają doskonale, i w dodatku z pierwszej ręki. O wiele słuszniej byłoby natomiast krzewić tam informacje o dokonaniach polskiej nauki, a na tej podstawie upowszechniać rzetelną wiedzę także o polskim społeczeństwie, bo przykładów żenującej ignorancji w tej mierze wśród autorów zagranicznych nie brakuje (vide artykuł Frances Pine - The cows and pigs are his, the eggs are mine, gdzie podano, że w latach 90 . na polskiej wsi mieszkało $60 \%$ ludności kraju, podczas gdy w rzeczywistości było to 38\% [Pine 1993]). Wypada tylko mieć nadzieję, że tacy autorzy nie są zatrudniani przez NCN w roli ekspertów i recenzentów oceniających projekty grantowe polskich badaczy...

Przywołany tu fakt notorycznego lekceważenia rodzimego dorobku i gonienia za kolejnymi światowymi modami naukowymi nie jest zresztą jakąś aktualną przypadłością, lecz doskonale wpisuje się w trwałą a niechlubną prawidłowość zdiagnozowaną przez Jana Stanisława Bystronia już w 1917 r. Jako bardzo niekorzystną cechę polskiej socjologii autor wskazywał jej „logiczny”, nie zaś „historyczny” rozwój, który polega na tym, że „autorzy polscy znajdują się zawsze w żywym kontakcie z teoriami obcymi, nie znając przeważnie poprzednich prac obcych" (Bystroń 1995, s. 540). W bardzo podobnym duchu wypowiadał się niewiele później, bo w 1920 r. Franciszek Bujak podczas odczytu inaugurującego obrady nad rozwojem nauki polskiej. Ubolewając nad faktem, że „więcej cenimy i lepiej znamy twórczość naukową obcą niż własną narodową", Bujak zauważał:

nie wystarcza korzystać wyłącznie z nauki innych narodów. Trzeba ją koniecznie hodować samemu u siebie, choćby dlatego, aby ją znać, umieć krytycznie ocenić oraz nią w pełni się posługiwać. Społeczeństwo ograniczające się do czerpania z cudzych źródeł i zasobów kulturalnych nie mogłoby rozwijać swojej indywidualności, ale przeciwnie, musiałoby się stawać częścią swojego duchowego 
żywiciela i wychowawcy, musiałoby patrzeć na świat i na siebie samo obcymi oczyma (Bujak 1976, s. 230-231).

Przenikliwość i aktualność diagnozy Bujaka potwierdza, niestety, znaczna część opracowań z czasów transformacji, gdyż ich autorzy do opisu i oceny polskiego społeczeństwa posługiwali się zazwyczaj schematami zaczerpniętymi z zachodnich podręczników. Co właściwie stanowi logiczną konsekwencję innej prawidłowości: imitacyjna transformacja doczekała się w ten sposób swojej imitacyjnej reprezentacji w naukach społecznych.

Niezbędnym warunkiem zerwania z tą niechlubną tradycją, odbudowania podmiotowości i suwerenności myślenia naukowego i tworzenia własnych teorii oraz nowych paradygmatów badawczych, wydaje się sięgnięcie do prac wcześniejszych pokoleń polskich autorów i skupienie uwagi na obszarach, które są szczególnie ważne dla analiz polskiego społeczeństwa. Takim obszarem jest właśnie problematyka wsi i rolnictwa, gdyż nie tylko odnosi się ona do kluczowych zagadnień całego polskiego społeczeństwa, ale też z racji swej specyfiki umożliwia wypracowanie oryginalnych podejść analitycznych i wreszcie - ma doniosły, ale w znacznym stopniu dopiero oczekujący na odkrycie i poznanie dorobek. Wbrew pozorom taki kierunek analiz wcale nie oznaczałby zaściankowości polskiej nauki, lecz wpisywałby się doskonale w aktualne procesy i potrzeby definiowane dla kontekstu europejskiego, a nawet globalnego. Wystarczy tu wspomnieć konkluzję konferencji na temat polityki UE wobec obszarów wiejskich (Cork - Irlandia 1996), gdzie w oficjalnym dokumencie stwierdzono, że to właśnie „obszary wiejskie i ich mieszkańcy stanowią wielki zasób UE”, oraz diagnozę Immanuela Wallersteina, który najpoważniejsze zagrożenie dla światowej gospodarki kapitalistycznej widział w procesach deruralizacji (Wallerstein 2004). Wszystko to dowodzi, że Polska - jako kraj o największym w UE odsetku powierzchni określanej jako „obszary wiejskie”, o największej i stale rosnącej liczbie mieszkańców wsi, wreszcie - posiadająca tak znaczne osiągnięcia w zakresie badania problemów wsi i rolnictwa - powinna ze szczególną troską pielęgnować, popularyzować i rozwijać swój dorobek w tym zakresie. Jest to bowiem warunkiem nie tylko należytego opisu i rozumienia aktualnej rzeczywistości, nie tylko czynnikiem zachowania ciągłości w rozwoju zainteresowań badawczych, ale również determinantą uzyskania dla polskich nauk społecznych należnej im pozycji międzynarodowej w światowym polu akademickim. 


\section{Bibliografia}

Adorno T. (2010). Osobowość autorytarna (tłum. M. Pańków). Warszawa: Wydawnictwo Naukowe PWN.

Archer M. (2013). Człowieczeństwo: Problem sprawstwa (tłum. A. Dziuban). Kraków: Nomos.

Bobako M. (2010). Konstruowanie odmienności klasowej jako urasowianie. W: P. Żuk (red.). Podziały klasowe i nierówności społeczne (s. 165-177). Warszawa: Oficyna Naukowa.

Bodenstedt A. (1998). Rolnictwo Europy: Wspólne dziedzictwo czy kość niezgody? W: Z.T. Wierzbicki, A. Kaleta (red.). Rolnictwo i wieś europejska (s. 17-32). Toruń: Uniwersytet Mikołaja Kopernika.

Buchowski M. (2008). Widmo orientalizmu w Europie. Recykling Idei, 10, 98-106.

Bujak F. (1976). Wybór pism. Warszawa: Państwowe Wydawnictwo Naukowe.

Bukraba-Rylska I. (2012). Socjologia wsi na UW. Wieś i Rolnictwo, 2, 151-157.

Burawoy M. (2011). The last Positivist. Contemporary Sociology: A Journal of Reviews, 40, 396-404.

Bystroń J.S. (1995). Rozwój problemu socjologicznego w nauce polskiej. W: J. Szacki (red.). Sto lat socjologii polskiej (s. 538-540). Warszawa: Państwowe Wydawnictwo Naukowe.

Chałasiński J. (1984). Młode pokolenie chłopów. Warszawa: Ludowa Spółdzielnia Wydawnicza.

Chałasiński J. (1995). Inteligenckie getto kultury polskiej. Regiony, 4, 9-26.

Domańska E. (2012). Historia egzystencjalna. Warszawa: Wydawnictwa Naukowe PWN.

Dowbor L. (2017). Co to za gra? Warszawa: Książka i Prasa.

Duda-Dziewierz K. (1938). Wieś małopolska a emigracja amerykańska. Warszawa-Poznań: Polski Instytut Socjologiczny.

Grabowska-Lusińska I., Okólski M. (2009). Emigracja ostatnia. Warszawa: Oficyna Naukowa.

Karczewska A. (2017). Czemu ten nasz chłop ciemny... Piaseczno: Wydawnictwo Nieoczywiste.

Kępiński A. (1992). Psychopatie. Warszawa: Sagittarius.

Kochanowicz J. (1992). Spór o teorię gospodarki chłopskiej. Warszawa: Uniwersytet Warszawski.

Komendera A. (1973). Socjologiczne monografie wsi w Polsce. Studia Socjologiczne, 2, 23-46.

Krzyworzeka A. (2014). Rolnicze strategie pracy i przetrwania. Warszawa: Uniwersytet Warszawski.

Kula W. (1962). Teoria ekonomiczna ustroju feudalnego. Próba modelu. Warszawa: Państwowe Wydawnictwo Naukowe.

Leder A. (2017). Referat na seminarium w Instytut Filozofii i Socjologii PAN - 16.10.2017. Leszczyński A. (2013). Skok w nowoczesność. Warszawa: Krytyka Polityczna.

Levine D. (1987). Reproducing Families: The Political Economy of English Population History. Cambridge: Cambridge University Press. 
Łopato J. (1988). Ideologiczno-ustrojowe przesłanki polityki rolnej PRL. W: J. Wilkin (red.). Gospodarka chłopska w systemie gospodarki socjalistycznej (s. 19-34). Warszawa: Uniwersytet Warszawski.

Malewska-Szałygin A., Rakowski T. (red.) (2011). Humanistyka i dominacja. Olsztyn: Instytut Etnologii i Antropologii Kulturowej UW.

Modzelewski K. (1987). Chłopi w monarchii wczesnopiastowskiej. Wrocław-Warszawa: Ossolineum.

Olszewska A. (1969). Wieś uprzemysłowiona. Wrocław: Ossolineum.

Pine F. (1993). The cows and pigs are his, the eggs are mine. W: C.M. Hann (red.). Socialism: Ideals, Ideologies and Local Practice (s. 227-242). London: Routledge.

Płatek D. (2016). Centra i peryferie polskiej socjologii ruchów społecznych. W: T. Zarycki (red.). Polska jako peryferie (s. 187-220). Warszawa: Wydawnictwo Naukowe Scholar. Pobłocki K. (2017). Kapitalizm. Historia krótkiego trwania. Warszawa: bęc zmiana.

Poleszczuk J. (1990). Społeczno-kulturowa geneza współczesnej socjologii empirycznej. W: A. Giza, E. Mokrzycki (red.). Teoria i praktyka socjologii empirycznej (s. 7-24). Warszawa: Instytut Filozofii i Socjologii PAN.

Romaniszyn K. (1994). Świat gospodarek ludzkich. Kraków: Uniwersytet Jagielloński.

Romaniszyn K. (2013). Rolnictwo w McŚwiecie. W: D. Kasprzyk (red.). Nie tylko o wsi... (s. 61-88). Łódź: Uniwersytet Łódzki.

Sadowski A. (1994). Procesy ruralizacji. Kraków-Białystok: Ekonomia i Środowisko.

Spengler O. (2001). Zmierzch Zachodu (tłum. J. Marzęcki). Warszawa: Wydawnictwo KR.

Styś W. (1959). Współzależność rozwoju rodziny wiejskiej i jej gospodarstwa. Wrocław: Ossolineum.

Szafraniec K. (2002). Polskie residuum systemowe, czyli pytanie o rolę wsi i chłopów w procesach przekształceń ustrojowych. Kultura i Społeczeństwo, 4, 31-56.

Szczepański J. (1971). Rola chłopów w rozwoju społeczeństwa polskiego. W: J. Szczepański (red.). Odmiany czasu teraźniejszego (s. 71-86). Warszawa: Książka i Wiedza.

Sztompka P. (2011). Another sociological utopia. Contemporary Sociology: A Journal of Reviews, 40, 388-396.

Thomas W., Znaniecki F. (1976). Chłop polski w Europie i Ameryce. T. 1 (tłum. M. Metelska). Warszawa: Ludowa Spółdzielnia Wydawnicza.

Tocqueville A., de (1994). Dawny ustrój i rewolucja (tłum. H. Szumańska-Grossowa). Kraków: Znak.

Wallerstein I. (2004). Koniec świata jaki znamy (tłum. M. Bilewicz, A.W. Jelonek, K. Tyszka). Warszawa: Wydawnictwo Naukowe Scholar.

Warczok T., Zarycki T. (2016). Gra peryferyjna. Polska politologia w globalnym polu nauk społecznych. Warszawa: Wydawnictwo Naukowe Scholar.

Wasilewski J. (1986). Społeczeństwo polskie: Społeczeństwo chłopskie. Studia Socjologiczne, 3, 41-68.

Wilkin J. (1988). Chłopski składnik losów gospodarki socjalistycznej: ze szczególnym uwzględnieniem polskich doświadczeń. W: J. Wilkin (red.). Gospodarka chłopska w systemie gospodarki socjalistycznej (s. 35-58). Warszawa: Uniwersytet Warszawski. 
Woś A. (2001). Konkurencyjność wewnętrzna rolnictwa. Warszawa: Instytut Ekonomiki Rolnictwa i Gospodarki Żywnościowej - PIB.

Yoshino E. (1997). Polscy chłopi w XX wieku. Warszawa: Semper.

Zarycki T. (2009). Peryferie. Warszawa: Wydawnictwo Naukowe Scholar.

Zarycki T. (red.) (2016). Polska jako peryferie. Warszawa: Wydawnictwo Naukowe Scholar. Zawistowicz-Adamska K. (1948). Społeczność wiejska. Łódź: Polski Instytut Służby Społecznej.

\title{
The Needs and Benefits of Exploring Rural and Agricultural Issues
}

\begin{abstract}
The article presents some reasons for cognitive, theoretical and methodological benefits of exploring rural and agricultural issues. Contrary to often repeated opinions, which exist owing to antyruralistic orientation in social sciences, orientalistic practices or urban chauvinism, these are not phenomena of small importance in contemporary world. They are still a considerable part of contemporary socio-economic reality. They have profound impact on a lot of other important phenomena; moreover, examining them also enables to verify or falsify common opinions, including the well-established scientific judgments. In light of subsequent global scientific achievements, the achievements of Polish rural sociology, rural economy or historical economy - featuring mostly interdisciplinary approach - turn to be in absolute vanguard in terms of significance. This shows that rural and agricultural issues continue to be a promising area for exploration.
\end{abstract}

Keywords: rusticity as a paradigm, interdisciplinary approach, chance for Polish science. 